\title{
DEMOCRACIA EM RISCO?
}

ABRANCHES, Sérgio et al. Democracia em risco? São Paulo: Companhia das letras: 2019.

\section{Luiz Rosado Costa ${ }^{1}$}

A obra de autoria coletiva, Democracia em risco?, publicada em $1^{\circ}$ de janeiro de 2019 se propôs ao desafio de, ainda no calor no momento, analisar os principais acontecimentos que afetaram a democracia brasileira nos últimos anos, especialmente a partir de 2013 até a eleição de Jair Bolsonaro à presidência da República em outubro de 2018.

Com textos de André Singer e Gustavo Venturi, Angela Alonso, Angela de Castro Gomes, Boris Fausto, Carlos Melo, Celso Rocha de Barros, Christian Dunker, Conrado Hübner Mendes, Daniel Aarão Reis, Esther Solano, Heloisa Starling, João Moreira Salles, José Arthur Giannotti, Matias Spektor, Monica de Bolle, Paula Louzano e Gabriela Moriconi, Petrônio Domingues, Renan Quinalha, Ronaldo de Almeida, Ronaldo Lemos, Ruy Fausto, Sérgio Abranches, os 22 ensaios que compõem a obra, foram escritos por autores de diversas áreas das ciências humanas e sociais, e buscam responder à pergunta do título do livro (Democracia em risco?), por meio da tentativa de compreensão dos fatores que levaram à polarização e à radicalização do debate político no Brasil.

Como alguns dos ensaios do livro observam², a polarização na sociedade brasileira não é fato isolado no mundo e adquiriu os mesmos contornos que se tem observado em países como os EUA de Donald Trump e a Hungria de Viktor Orban, onde se observa uma ascensão da extrema direita ao poder. A polarização da política e a ascensão de Bolsonaro seriam, assim, a expressão no Brasil de um fenômeno mais amplo de ascensão da extrema direita, de retórica conservadora em matéria de costumes, mas, ultraliberal em assuntos de ordem econômica.

Em seu ensaio de abertura, Sérgio Abranches aventa a hipótese de que essa transição global tem como característica a perda de referências: num mundo de incertezas, as pessoas se apegariam mais às identidades de grupo que lhe deem segurança. $\mathrm{O}$ indivíduo entra no que Christian Ingo Lenz Dunker chama de "estado de massa" (digitais).

Os textos demonstram que manifestações de junho de 2013 colocaram em xeque a estabilidade de um sistema político que parecia consolidado e, desde então - a eleição polarizada de 2014, as manifestações de 2015 contra o governo Dilma, a descoberta de arraigados esquemas de corrupção, o avanço da Operação Lava Jato, o controvertido impeachment da Presidenta e a prisão

1 Mestre em Direito pela Universidade Federal de Mato Grosso do Sul. E-mail: luizrosadocosta@gmail.com

2 Cf. os ensaios de Sérgio Abranches, Boris Fausto, Angela Castro Gomes e Matias Spektor. 
do ex-presidente Luiz Inácio Lula da Silva - o país entrou em uma crise política que suscitou diversas questões sobre suas causas e gerou apreensões em relação ao futuro e continuidade da democracia.

A obra traz amplas reflexões sobre o futuro da democracia e a maior responsabilidade que recai às instituições e à sociedade para a sua manutenção, mas apresenta um discurso unânime num contexto polarizado pois carece da exposição de opiniões contrárias às dos autores para que se possa fazer o contraponto.

Ainda é necessário um maior distanciamento histórico dos fatos para que a resposta proposta no título da obra seja respondida de maneira mais objetiva e menos emocional por quem viveu e está vivendo os fatos. Assim, embora não responda (nem possa) de maneira definitiva responder à pergunta de seu título, a obra traz importantes reflexões para que se pensem caminhos a fim de que a resposta seja negativa e a democracia sobreviva aos tempos de turbulência que atravessa. 